\title{
STRATEGI PEMBERDAYAAN MASYARAKAT DI KAWASAN HUTAN SEBAGAI LANGKAH ANTISIPATIF DALAM PENANGANAN BENCANA BANJIR DAN TANAH LONGSOR DI KABUPATEN TRENGGALEK
}

\begin{abstract}
Windiani* $^{*}$
Abstrak

Kabupaten Trenggalek sebagian besar merupakan wilayah pegunungan dengan luasan wilayah 126.140 ha dan mayoritas penduduknya bermatapencaharian sebagai petani. Namun ironisnya penggunaan tanah terbesar justru adalah hutan Negara seluas 60,936 ha atau $48,31 \%$ dari total wilayah Kabupaten Trenggalek. $\mathrm{Hal}$ ini dapat berdampak kurang menguntungkan bagi sebagian besar masyarakat setempat, jika penggunaan lahan untuk hutan Negara tersebut tidak melibatkan masyarakat setempat. Di sisi lain dengan kondisi geografis besar pegunungan dan sebagian dataran rendah kabupate Trengalek juga merupakan wilayah rawan bencana banjir dan tanah longsor. Jika kondisi sebagian besar hutan Negara pengelolaannya kurang lestar,maka punya kontribusi yang besar terhadap kerawanan seperti banjir dan tenah longsor. Sehingga pelibatan dan pemberdayaan masyarakat di sekitar kawasan merupakan upaya strategis untuk melestarikan hutan dan mengantisipasi bencana banjir dan tanah longsor.
\end{abstract}

Kata kunci: Strategi Pemberdayaan, Masyarakat, Hutan, Antisipatif, Penangan Bencana, Banjir, Longsor

Kabupaten Trenggalek merupakan wilayah yang 2/3 (dua per tiga) wilayahnya merupakan wilayah pegunungan dengan luas wilayah 126.140 ha yang terbagi dalam 14 kecamatan dan 157 desa. Total penduduk 687.477 jiwa. Sebagaian besar penduduk mengandalkan kehidupannya dari sektor pertanian dengan luasan lahan pertanian untuk persawahan 11.806 ha, lahan kering 46.894 ha dan untuk perkebunan 3.825 ha. Dari sebagian luasan wilayah yang ada, penggunaan lahan terbesar yaitu $48,31 \%$ peruntukannya adalah untuk hutan negara. Ini berarti bahwa pengelolaan sebagian besar lahan yang ada di kabupaten Trenggalek berada di bawah pengelolaan Dinas Kehutanan melalui Perhutani.

Berdasarkan peta wilayah rawan bencana di Jawa Timur (2008) Kabupaten Trenggalek juga merupakan salah satu wilayah rawan bencana banjir dan tanah longsor yang perlu perhatian semua pihak khususnya pemerintah dan masyarakat setempat untuk dapat melakukan langkah-langkah antisipatif dalam menghadapi bencaana banjir dan longsor yang datang sewaktu-waktu. Seperti banjir bandang tahun 2006 yang lalu yang telah menenggelamkam kawasan perkotaan di kabupaten

\footnotetext{
* Dosen pada UPM Soshum ITS

jsh Jurnal Sosial Humaniora, Vol 3 No.1, Juni 2010 
Trenggalek dengan datangnya air bah yang sangat cepat sehingga penduduk tidak mampu melakukan tindakan apapun untuk menyelamatan harta benda.

Banjir bandang dan tanah longsor yang terjadi hampir setiap tahun ditengarai karena banyaknya alih fungsi hutan, khususnya hutan rakyat dari hutan tanaman produksi menjadi hutan tanaman semusim seperti jagung, ketela kacang tanah dan tanaman powijo lainnya. Sementara itu hutan negara di bawah pengelolaan Dinas Perhutani dipandang sangat sentris dan kurang melibatkan masyarakat dalam pengelolaannya, sehingga masyarakat cenderung membiarkan kawasan hutan milik negara termasuk ketika terjadi illegal loging dan penjarahan hasil-hasil hutan milik perhutani.

Pengelolaan penggunaan lahan seperti kawasan hutan yang berada di sekitar hunian penduduk tidak jarang menimbulkan berbagai permasalahan antara lain; kontradiksi antara kebutuhan dan batasan-batasan yang berat demi lingkungan hidup, meningkatnya keperluan hidup, terjadinya kerusakan tanah karena kurang pemeliharaan, lemahnya pengawasan dan kurang dilibatkannya masyarakat setempat dalam pengelolaan kawasan hutan. Berdasarkan hal tersebut di atas perlu kiranya menjaga kelestarian hutan yang dapat memberikan manfaat bagi ekonomi rakyat dan bagi lingkungan.

\section{Hutan dan permasalahan Lingkungan}

Pada dasarnya masalah lingkungan timbul sebagai akibat dari ulah manusia itu sendiri . Manusia dalam memanfaatkan sumber daya alam akan menimbulkan perubahan terhadap ekosistem yang akan mempengaruhi kelestarian sumber daya alam itu sendiri. Pemanfaatan sumber daya alam yang melebihi ambang batas daya dukung lahan dan tanpa memperhatikan aspek kelestariannya akan mendorong terjadinya erosi dan longsor, seperti yang banyak terjadi sekarang ini. Akibat dari keadaan tersebut menyebabkan terjadinya degradasi lahan, pendangkalan sungai , dan terganggunya sistem hidrologi Daerah Aliran Sungai (DAS). Dampak selanjutnya dapat memicu terjadinya bencana banjir dan longsor.

Kebakaran hutan yang sering terjadi akan membumihanguskan habitat satwa, mengurangi keragaman hayati dan menghilangkan kesuburan tanah, rusaknya siklus 
hidrologi serta akan menimbulkan pemanasan global. Banyaknya perladangan berpindah akan semakin meningkatkan ancaman kerusakan hutan, karena umumnya masyarakat tidak memperhatikan aturan - aturan yang benar untuk menjaga kelestarian hutan dalam melakukan aktivitasnya di ladang (Marison Guciano, 2009).

Menurut FAO masalah lingkungan di negara-negara berkembang sebagian besar disebabkan karena eksploitasi lahan yang berlebihan, perluasan penanaman dan penggundulan hutan (Reyntjes, Coen et.al. 1999). Bersamaan dengan meningkatnya jumlah penduduk dan industrialisasi, permasalahan penggunaan lahan sudah umum terjadi. Pemikiran secara intuitif dalam penggunaan lahan sudah sejak lama dilakukan, tetapi penggunaan secara lebih efisien dan dengan perencanaan baru terwujud jelas setelah perang dunia I ( Sandy, 1980).

Sebagai sumber daya alam, hutan mempunyai multi fungsi sangat penting bagi kehidupan. Tajuk pohon yang banyak dan berlapis-lapis pada tanaman yang ada di hutan akan sangat membantu untuk menahan energi potensial air hujan yang jatuh sehingga aliran air tidak terlalu besar, hal ini akan mengurangi kerusakan tanah, baik erosi percikan maupun erosi alur. Kondisi ini akan membantu kesuburan tanah dan penyerapan air tanah. Secara global hutan adalah paru-paru dunia karena akan menyerap karbon dioksida di udara dan melepaskan oksigen yang lebih banyak yang sangat bermanfaat bagi makhluk hidup di dunia.

Menurut Departemen Pertanian, 2006. Kawasan hutan pegunungan merupakan hulu Daerah Aliran Sungai (DAS) yang berfungsi sebagai penyangga tata air daerah hilir, pleh karena itu perlu dilakukan pengelolaan lahan yang tepat agar dapat melakukan pelestarian Sumber Daya Alam dan lingkungan terutama kawasan hilir yang akan mempengaruhi kegiatan pertanian dan ekonomi setempat.

\section{Pelestarian Hutan}

Mengkaji tentang hutan, biasanya akan berkaitan dengan pegunungan, sebab kawasan hutan adalah merupakan kawasan pegunungan seperti yang terjadi di kabupaten Trenggalek. Lahan di pegunungan yang masih merupakan kawasan hutan adalah lahan yang sangat banyak memberikan manfaat untuk pertanian, selain itu hutan juga sangat penting untuk menjaga fungsi lingkungan Daerah Aliran Sungai (DAS) dan penyangga daerah di bawahnya. 
Istilah pelestarian mengesankan penimbunan, seakan akan gagasan tersebut hanyalah berarti persediaan tetap cadangan, sehingga ada sesuatu yang tertinggal untuk masa yang akan datang. Dalam pandangan masyarakat awam ahli pelestarian terlalu sering digambarkan sebagai orang yang bersifat anti sosial yang menentang setiap macam pembangunan. Apa yang sebenarnya ditentang oleh para ahli pelestarian adalah pembangunan yang tanpa rencana yang melanggar hukum ekologi dan hukum manusia.

Pelestarian dalam pengertian yang luas merupakan salah satu penerapan yang penting dari ekologi. Tujuan dari pelestarian yang sebenarnya adalah memastikan pengawetan kualitas lingkungan yang mengindahkan estitika dan kebutuhan maupun hasilnya serta memastikan kelanjutan hasil tanaman, hewan, bahan-bahan yang berguna dengan menciptakan siklus seimbang antara panenan dan pembaharuan. Kesadaran lingkungan harus ditumbuhkembangkan pada masyarakat sejak dini . Tekanan sosial dan ekonomi masyarakat yang menggantungkan hidupnya pada sumber daya alam dapat ditumbuhkembangkan melalui upaya pemberian informasi tentang lingkungan sehingga akan meningkatkan kesadaran lingkungan masyarakat.

Menurut Djaenudin, D. 1994 kawasan hutan perlu dipertahankan berdasarkan pertimbangan fisik, iklim dan pengaturan tata air serta kebutuhan sosial ekonomi masyarakat dan Negara. Hutan yang dipertahankan terdiri dari hutan lindung, hutan suaka alam, hutan wisata, hutan konservasi, hutan produksi terbatas dan hutan produksi. Berikut ini pengertian dari berbagai jenis hutan tersebut, antara lain: (1) Hutan lindung adalah hutan yang perlu dibina dan dipertahankan sebagai hutan dengan penutupan vegetasi secara tetap untuk kepentingan hidroorologi, yaitu mengatur tata air, mencegah banjir dan erosi, memelihara keawetan dan kesuburan tanah baik dalam kawasan hutan bersangkutan maupun kawasan yang dipengaruhi di sekitarnya; (2) Hutan suaka alam adalah hutan yang perlu dipertahankan dan dibina keanekaragaman jenis tumbuhan dan satwa, tipe ekosistem, gejala dan keunikan alam bagi kepentingan plasma nutfah dan pengetahuan, wisata dan lingkungan; (3) Hutan wisata adalah hutan yang dipertahankan dengan maksud untuk mengembangkan pendidikan, rekreasi dan olahraga; (4) Hutan konservasi 
adalah hutan yang dipertahankan untuk keberadaan keanekaragaman jenis plasma nutfah dan tempat hidup dan kehidupan satwa tertentu; (5) Hutan produksi terbatas adalah kawasan hutan untuk menghasilkan kayu hutan yang hanya dapat dieksploitasi secara terbatas dengan cara tebang pilih serta; (6) Hutan produksi adalah kawasan hutan yang diperuntukkan sebagai kebutuhan perluasan, pengembangan wilayah misalnya transmigrasi pertanian dan perkebunan, industri dan pemukiman dan lain-lain.

Di dalam hutan-hutan tersebut di atas tidak boleh dilakukan kegiatan yang mengakibatkan terganggunya fungsi hutan tersebut. Hutan mempunyai fungsi pelindung terhadap tanah dari tetesan hujan yang jatuh dari awan yang mempunyai energi tertentu, karena gerak jatuhnya itu dengan energi tertentu tetesan hujan akan memukul permukaan tanah dan melepaskan butiran tanah sehingga akan terjadi erosi percikan.

Air hujan yang tidak meresap ke dalam tanah akan mengalir di atas permukaan tanah, aliran air ini mempunyai energi tertentu juga, makin curam dan panjangnya lereng tempat air mengalir makin besar energinya, energi yang ada pada aliran permukaan ini akan mengelupaskan permukaan tanah sehingga terjadi erosi permukaan. Aliran permukaan dapat juga menyebabkan terbentuknya alur permukaan tanah yang disebut dengan erosi alur.

Jika ada hutan maka tetesan air hujan akan jatuh pada tajuk-tajuk tanaman yang ada di hutan tersebut, terlebih lagi bila tajuk tersebut berlapis-lapis sebagian air hujan tersebut, akan menguap kembali ke udara dan sebagian lagi akan jatuh ke tanah melalui tajuk- tajuk tanaman dari yang teratas sampai ke tajuk tanaman yang terendah, akibatnya energi kinetic air hujan tersebut di patahkan atau diturunkan kekuatannya oleh tajuk- tajuk tanaman yang berlapis tadi, hingga akhirnya air hujan yang jatuh pada tanah dari tajuk yang terendah energinya hanya yang kecil saja sehingga kekuatan pukulan air hujan pada permukaan tanah tidak besar, dengan demikian erosi percikan hanya kecil.

Sebagian air yang jatuh di tajuk akan mengalir melalui dahan ke batang pokok dan selanjutnya mengalir ke bawah melalui batang pokok sampai ke tanah. Di dalam hutan di atas permukaan tanah terdapat seresah yaitu, daun, dahan dan kayu 
yang membusuk. Seresah- seresah tersebut dapat menyerap air dan dapat membuat tanah mejadi gembur dan membuat air mudah meresap ke dalam tanah. Karena penyerapan air oleh seresah dan air meresap ke dalam tanah aliran air permukaan menjadi kecil dengan demikian erosi lapisan dan erosi alur jadi kecil.

Apabila hutan tidak dipertahankan atau dilestarikan fungsi perlindungan hutan terhadap tanah akan hilang sehingga akan terjadi erosi bahkan longsor seperti yang banyak terjadi sekarang ini bila musim hujan datang. Erosi akan semakin besar dengan besarnya intensitas hujan serta makin curam dan panjangnya lereng. Akibat adanya erosi kesuburan tanah akan berkurang karena lapisan atas sudah terkikis dan terbawa oleh air sehingga akan menurunkan produksi tanaman dan pendapatan petani (Sinukaban, N. 1994).

\section{Upaya Pelestarian Hutan}

Sumber masalah kerusakan lingkungan terjadi sebagai akibat dilampauinya daya dukung lingkungan, yaitu tekanan penduduk terhadap lahan yang berlebihan. Kerusakan klingkungan hanyalah akibat atau gejala saja , karena itu penanggulangan kerusakan lingkungan itu sendiri hanyalah merupakan penanggulangan yang sistematis, yaitu penanggulangannya harus dilakukan lebih mendasar yang berarti menanggulangi penyebab dari kerusakan lingkungan. Karena itu sebab keruskan lingkungan yang berupa tekanan penduduk terhadap sumber daya alam yang berlebih harus ditangani.

Upaya pelestarian hutan dapat dilakukan dengan mencegah perladangan berpindah yang tidak menggunakan kaidah pelestarian hutan, waspada dan hati- hati terhadap api dan reboisasi lahan gundul serta tebang pilih tanam kembali (Organisasi Komunitas dan Perpustakaan Online Indonesia, 2006).

Perladangan berpindah sering dilakukan oleh masyarakat yang bermukim di pedesaan. Pengaruhnya terhadap pelestarian hutan tidak akan besar karena mereka dalam melakukan kegiatan pada lahan yang tidak terlalu luas. Cara yang mereka gunakan biasanya masih tradisional dan usaha taninya bersifat subsisten dan mereka tidak menetap. Namun untuk perladangan yang luas perlu dilakukan usaha tani yang memenuhi kaidah-kaidah pelestarian hutan dan harus ada pencagahan perladangan berpindah. 
Seringnya terjadi pembakaran hutan pada lahan-lahan perkebunan yang besar memberikan dampak yang buruk pada hutan disekitarnya. Oleh sebab itu perlu dihindari pembukaan lahan baru dengan cara pembakaran hutan. Kebakaran hutan juga dapat terjadi bila tidak hati-hati terhadap api, membuang sisa rokok yang tidak pada tempatnya akan dapat menjadi sumber api, pembakaran sampah atau sisa tanaman yang ada di ladang tanpa pengawasan dan penjagaan juga dapat menjadi sumber kebakaran.

Biaya yang dikeluarkan untuk reboisasi dan penghijauan sudah sangat besar namun hasilnya tidak menggembirakan, banyak pohon yang ditanam untuk penghijauan dan reboisasi dimatikan lagi oleh penduduk karena perpindahan ladang dan pembukaan lahan baru, untuk itu salah satu cara yang dapat dilakukan untuk reboisasi adalah dengan sistem tumpang sari, dalam sistem ini peladang diperbolehkan menanam tanaman pangan diantara larikan pohon dengan perjanjian petani memelihara pohon hutan yang ditanam dan setelah kira-kira lima tahun waktu pohon sudah besar petani harus pindah, namun dalam kenyataan petani banyak tidak memelihara pohon atau bahkan mematikan pohon tersebut karena dianggap mengganggu tanaman usaha taninya sehingga tidak jarang mereka menetap di tempat tersebut.

Kegagalan penghijauan dan reboisasi dapat dimengerti, karena penghijauan dan reboisasi itu pada hakikatnya menurunkan daya dukung lingkungan. Dalam hal penghijauan, pohon ditanam dalam lahan petani yang digarap, pohon itu mengambil ruas tertentu sehingga jumlah luas lahan yang tersedia untuk tanaman petani berkurang. Lagi pula pohon itu akan menaungi tanaman pertanian dan akan mengurangi hasil. Oleh sebab itu, petani akan mematikan pohon atau memangkas pohon tersebut untuk mengurangi naungan dan mendapatkan kayu bakar.

Reboisasi mempunyai efek yang serupa seperti penghijauan yaitu, mengurangi luas lahan yang dapat ditanami oleh petani dan pengurangan produksi oleh naungan pohon. Jadi jelas dari segi ekologi manusia penghijauan dan reboisasi sukar untuk berhasil selama usaha itu mempunyai efek menurunkan daya dukung lingkungan dan menghilangkan atau mengurangi sumber pencaharian penduduk. 


\section{Potensi Ekonomi Dari Pelestarian Hutan}

Pelestarian hutan memiliki potensi ekonomi yang besar jika dilakukan dengan upaya yang optimal. Nilai ekonomi yang dihasilkan dari masing-masing tipe pemanfaatan sumber daya alam (hasil hutan kayu, non kayu, tambang, perikanan, pertanian, pariwisata, dll.) serta nilai ekonomi dari jasa lingkungan yang disediakan oleh kawasan hutan, hendaknya tidak dilihat sebagai nilai-nilai yang terpisah satu sama lain, karena setiap kegiatan pemanfaatan sumber daya alam (kegiatan ekonomi lain) tidak berdiri sendiri, melainkan saling berinteraksi dan saling memberikan dampak satu sama lain.

Prinsip-prinsip yang menyangkut faktor pembatas dan produktivitas di masa lalu telah menetapkan pokok penerapan ekologi untuk pertanian dan kehutanan, tetapi untuk alasan-alasan yang telah dikemukakan, para ahli pertanian dan kehutanan sekarang harus berfikir bahwa tanaman dan hutannya mempunyai hasil lain selain dari makanan dan serat, dalam pengertian ekosistem manusia secara keseluruhan.

Komponen-komponen sistem pertanian berinteraksi secara sinergis ketika komponen-komponen itu terlepas dari fungsi utamanya, meningkatkan kondisikondisi bagi komponen lain yang berguna di dalam sistem pertanian, misalnya; menciptakan iklim mikro yang cocok bagi komponen lain, menghasilkan senyawa kimia untuk mendorong komponen yang diinginkan atau menekan komponen yang berbahaya (pengaruh alelopatis dari pengeluaran akar atau mulsa)., memproduksi pelapis tanah atau struktur akar untuk meningkatkan konservasi air dan tanah,mengusahakan sistem akar yang dalam untuk meningkatkan daur ulang air dan unsur hara. Kurangnya pengetahuan masyarakat tentang keterkaitan setiap komponen pertanian maupun komponen kehidupan membuat mereka lupa bahkan tidak mengetahui sama sekali bahwa hutan sangan mempengaruhi kehidupan disekitarnya.

Manfaat atau fungsi hutan bagi kehidupan manusia secara langsung maupun tidak langsung sangat banyak dan beragam. Hutan tidak saja sebagai sumber kayu dan hasil hutan lainnya yang memberikan manfaat ekonomi. Secara tidak langsung hutan akan memberikan pengaruh pada kehidupan di hilirnya. Hutan juga 
mempunyai fungsi perlindungan terhadap tata air. Dengan adanya seresah di lantai hutan dan struktur tanah gembur, air hujan terserap dan masuk ke dalam tanah. Karena itu dalam musim hujan debit maksimum air dapat dikurangi, dengan demikian bahaya banjir berkurang.

Hujan yang jatuh ke bumi baik langsung menjadi aliran maupun tidak langsung melalui vegetasi atau media lainnya akan membentuk siklus aliran air mulai dari tempat yang tinggi (gunung, pegunungan ) menuju ke tempat yang rendah baik di permukaan tanah maupun di dalam tanah yang berakhir di laut. Sebagian air hujan yang jatuh di permukaan tanah meresap ke dalam tanah dalam bentuk infiltrasi, perkolasi, kapiler. Aliran air tanah dapat dibedakan menjadi aliran tanah dangkal, aliran tanah dalam, aliran tanah antara dan aliran tanah dasar. Disebut aliran tanah dasar karena aliran ini merupakan aliran yang mengisi sisten jaringan sungai. Hal ini dapat di lihat pada musim kemarau aliran ini akan tetap secara kontinyu apabila kondisi hutan baik (Kodoatie, R.2005). Oleh sebab itu kilta perlu melestarikan hutan.

Banyaknya air hujan yang meresap ke dalam tanah, persediaan air tanah akan bertambah. Sebagian air tanah akan keluar lagi di daerah yang lebih rendah sebagai mata air, dengan bertambahnya cadangan air tanah, mata air serta sumur yang hidup di musim kemarau juga lebih banyak daripada tanpa adanya hutan. Jadi, efek hutan adalah mengurangi resiko kekurangan air dalam musim kemarau.

Air sebagai sumber kehidupan mempunyai berbagai macam fungsi . Di sisi lain air juga merupakan bagian dari sumber daya alam . Fungsi air sebagai sumber kehidupan adalah memenuhi kebutuhan air baku untuk rumah tangga, pertanian, industry, pariwisata, pertahanan, pertambangan, ketenagaan dan perhubungan. Sebagai sumber daya alam air juga harus dilestarikan agar ketersediaan air dipermukaan bumi ini bisa berkesinambungan. Dengan melestarikan hutan berarti kita juga melestarikan ketersediaan air sebagai sumber daya alam.

Banyaknya air yang tersedia di permukaan bumi ini akan sangat membantu kehidupan manusia karena air diantaranya akan banyak memberikan manfaat ekonomi. Di daerah daerah yang pengairannya baik pertanian tidak lagi bergantung pada hujan, petani dapat merencanakan pola pergiliran tanaman dengan lebih baik. 
Di daerah-daerah hilir hutan pegunungan masyarakatnya akan merasakan manfaat yang sangat menguntungkan bila pelestarian hutan terjaga dan melibatkan masyarakat setempat dalam melestarikan keseimbangan ekosistem dalam hutan akan memelihara tata air di sekitarnya. Masyarakat yang ada di dataran rendah juga bisa memanfaatkan sumberdaya air yang tersedia untuk keperluan hidupnya maupun untuk aktivitas perekonomian.

Secara tidak langsung sumber daya air akan memberikan manfaat ekonomi pada rumah tangga dan pertanian. Rumah tangga yang mempunyai industri akan membutuhkan air untuk usahanya, petani dalam berusaha tani juga sangat membutuhkan air, baik untuk penyemprotan maupun untuk kebutuhan tanaman itu sendiri. Tanaman yang kekurangan air pertumbuhannya akan terganggu, produktivitas akan berkurang bahkan akan terancam mati. Sebaliknya bila sumber air tersedia tanaman akan tumbuh dengan baik dan produksinya akan tinggi.

Selain dari manfaat yang tidak langsung, masyarakat disekitar kawasan hutan juga bisa memanfaatkan hasil hutan langsung dengan tidak secara berlebihan dan tetap berusaha adanya pembaharuan untuk menjaga kelestariannya. Hasil hutan yang didapatkan bisa untuk konsumsi sendiri atau untuk di jual sehingga dapat menjadi pendapatan tambahan.

Manusia harus ingat bahwa kebutuhan terus meningkat dan berubah dari waktu ke waktu, untuk dapat mendukung kebutuhan yang meningkat dan berubah itu perlu adanya sumberdaya yang berkesinambungan. Lingkungan kita merupakan sumberdaya, karena itu harus kita manfaatkan dengan bijaksana agar daya dukung terlanjutkan dapat terpelihara untuk dapat menjamin tingkat hidup yang makin tinggi.

Dari uraian-uraian yang telah disebutkan sebelumnya jelas bahwa banyak manfaat ekonomi yang akan diperoleh bila kita melestarikan hutan. Selain dari dalam hutan itu sendiri di wilayah sekitar hutan dan di daerah hilirnya manfaat ekonomi akan banyak diperoleh. 


\section{Pelestarian Hutan dan Lingkungan Melalui Strategi Pemberdayaan Masyarakat Di Sekitar Kawasan Hutan}

Ancaman kerusakan hutan dari hari ke hari semakin meningkat, sebagian besar kerusakan hutan adalah karena adanya pembukaan lahan baru yang tidak mengikuti kaidah ekologi atau lingkungan. Banyak sekali hutan dirusak hanya untuk kepentingan tertentu dari individu maupun kelompok atau institusi tanpa ada pertimbangan untuk pelestariannya. Adanya pengembangan wilayah pemukiman, atau daerah pemekaran yang membutuhkan lahan baru untuk pembangunan daerahnya akan mengakibatkan dibukanya hutan. Akibat dari semuanya ini akan merusak keseimbangan ekosistem lingkungan, hutan yang sudah banyak rusak akan memberi pengaruh buruk pada lingkungan.

Jika hutan kita menjadi gundul atau terbakar, sehingga lingkungan hidup kita rusak, siapa biang keladinya? Penduduk miskin di hutan-hutan dan sekitar hutan menebang hutan negara untuk memperoleh penghasilan untuk makan. Tetapi kayukayu yang diperolehnya ditampung calo-calo untuk dijual, dan kemudian dijual lagi untuk ekspor, yang semuanya “demi keuntungan”. Siapa yang paling bersalah dalam proses perusakan lingkungan ini? (Mubyarto, 2004)

Lingkungan adalah kombinasi antara kondisi fisik yang mencakup keadaan sumber daya alam seperti tanah, air, energi surya, mineral, serta flora dan fauna yang tumbuh di atas tanah maupun di dalam lautan, dengan kelembagaan yang meliputi ciptaan manusia seperti keputusan bagaimana menggunakan lingkungan fisik tersebut. Lingkungan terdiri dari komponen abiotik dan biotik. Komponen abiotik adalah segala yang tidak bernyawa seperti tanah, udara, air, iklim, kelembaban, cahaya, bunyi. Sedangkan komponen biotik adalah segala sesuatu yang bernyawa seperti tumbuhan, hewan, manusia dan mikro-organisme (virus dan bakteri). Lingkungan, di Indonesia sering juga disebut "lingkungan hidup". Misalnya dalam Undang-Undang no. 23 tahun 1997 tentang Pengelolaan Lingkungan Hidup, definisi Lingkungan Hidup adalah kesatuan ruang dengan semua benda, daya, keadaan, dan makhluk hidup, termasuk manusia, dan perilakunya, yang mempengaruhi kelangsungan perikehidupan dan kesejahteraan manusia serta makhluk hidup lain (Wikipedia Ensiklopidia Bebas Indonesia, 2009). 
Dengan pemahaman lingkungan hidup diatas, maka upaya pelestarian lingkungan hidup adalah upaya pelestarian komponen-komponen lingkungan hidup beserta fungsi yang melekat dan interaksi yang terjadi diantara komponen tersebut. Adanya perbedaan fungsi antara komponen dan pemanfaatan dalam pembangunan, maka pelestarian tidak dipahami sebagai pemanfaatan yang dibatasi. Namun pelestarian hendaknya dipahami sebagai pemanfaatan yang memperhatikan fungsi masing-masing komponen dan interaksi antar komponen lingkungan hidup dan pada akhirnya, diharapkan pelestarian lingkungan hidup akan memberikan jaminan eksistensi masing-masing komponen lingkungan hidup.

Dengan adanya jaminan eksistensi, lingkungan hidup yang lestari dapat diwujudkan. Upaya pelestarian lingkungan hidup yang telah dilakukan oleh banyak pihak selama ini menunjukan banyak keberhasilan dan tidak sedikit yang mengalami hambatan dalam mencapai tujuan yang ingin dicapai dalam masing-masing aspek. Upaya-upaya tersebut lebih terlihat sebagai gerakan yang berdiri sendiri di masingmasing lokasi, kasus dan aspek lingkungan yang dihadapi. Selain itu, upaya pelestarian yang telah dilaksanakan kurang dirasakan manfaat/kegunaan baik secara jangka menengah maupun jangka panjang, hal ini terjadi karena kurangnya kepedulian dan pengetahuan serta informasi yang jelas dan menyeluruh tentang manfaat pelestarian hutan bagi aspek kehidupan yang lainnya dan bagi lingkungan secara luas.

Melestarikan hutan berarti melestarikan lingkungan hidup, karena dengan menyelamatkan hutan berarti juga menyelamatkan semua komponen kehidupan. Jika kita mengetahui mengenai sesuatu mengenai potensi alam dan faktor-faktor yang membatasi kita dapat menentukan penggunaan terbaik. Ekosistem-ekosistem baru yang berkembang yang diciptakan manusia, seperti pertanian padang rumput, gurun pasir yang diairi, penyimpanan-penyimpanan air, pertanian tropika akan bertahan untuk jangka waktu lama hanya jika keseimbangan-keseimbangan material dan energi tercapai antara komponen-komponen biotik dan fisik. Karena itu penting sekali untuk melestarikan hutan.

Melakukan pelestarian hutan sama dengan menyelamatkan ekosistem dari hutan itu sendiri, ekosistem terbentuk oleh komponen hidup dan tak hidup di suatu 
tempat yang berinteraksi membentuk suatu kesatuan yang teratur. Keteraturan itu terjadi oleh adanya arus materi dan energi yang terkendalikan oleh arus informasi antara komponen dalam ekosistem itu. Masing-masing komponen mempunyai fungsi atau relung, selama masing-masing komponen itu melakukan fungsinya dan bekerja sama dengan baik, keteraturan ekosistem itupun terjaga. Keteraturan ekosistem menunjukkan ekosistem tersebut ada dalam suatu keseimbangan tertentu. Keseimbangan itu tidak bersifat statis malainkan dinamis, ia selalu berubah-ubah, kadang-kadang perubahan itu besar dan kadang-kadang kecil. Perubahan itu dapat terjadi secara alamiah maupun sebagai perbuatan manusia (Soemarwoto, 2000).

Pada kenyataannya unsur-unsur yang ada dalam lingkungan hidup tidak bisa berdiri sendiri, melainkan harus terintegrasi dengan komponen lain yang berkaitan dalam suatu sistem. Pelestarian dan menyelamatkan hutan, berarti menyelamatkan lingkungan, hutan yang mempunyai multi fungsi akan menyelamatkan semua komponen kehidupan di bumi ini bila manusia mau melestrikannya. Penting kiranya melestarikan hutan dengan melihat peran strategis masyarakat yang ada di sekitar kawasan untuk terlibat di dalamnya baik dalam proses perencanaan, pengelolaan hingga mekanisme pasar terkait dengan hasil-hasil hutan. Jika strategi ini dilakukan hutan akan membawa manfaat yang sangat besar bagi lingkungan, masyaakat dan secara global hutan memberikan kontribusi bagi paru-paru dunia dan dapat mengurangi pemanasan suhu bumi, yang pada akhirnya bisa mencegah kekeringan saat kemarau dan mencegah banjir dan longsor saat musim hujan.

\section{Kesimpulan}

1. Pelestarian hutan perlu melibatkan masyarakat setempat agar memberikan manfaat ekonomi sosial dan bagi keberlanjutan lingkungan itu sendiri.

2. Pelibatan masyarakat bisa menjadi bagian dari strategi pemberdayaan masyarakat untuk mengantisipasi wilayah atau kawasan yang rawan bencana banjir dan tanah longsor.

3. Strategi pemberdayaan masyarakat ini bisa dilakukan dengan melibatkan masyarakat mulai pada tahap perencanaan, pengelolaan hutan, pengawasan hingga dilibatkan dalam proses penentuan harga terkait dengan hasil-hasil hutan. 
161 - Strategi Pemberdayaan Masyarakat di Kawasan Hutan .........

4. Pelestarian hutan memberikan dampak luas terhadap peningkatan kualitas ekosistem (biotik dan atau fisik) lingkungan di dalam dan luar kawasan hutan.

\section{Referensi}

Salim, Emile, Pembangunan Berwawasan lingkungan, LP3ES, 1998

Muktasor, (Ed), Pengantar Ilmu Lingkungan, ITS Press, 2008

Mulyadi, Visi Misi Pembangunan Kabupaten Trenggalek, 2010

Soemarwoto, Otto, Ekologi dan Pembangunan, Penerbit Djambatan, 2000 